\title{
EFFICIENCY EVALUATION OF USING LUBRICANTS WITH FULLERENE COMPOSITIONS DURING OPERATION OF TRUCKS IN THE URBAN DRIVING CYCLE
}

\author{
Andriy Kravtsov ${ }^{1}$; Mykola Karnaukh ${ }^{1}$; Lubomir Slobodyan ${ }^{2}$
}

\author{
${ }^{1}$ Kharkiv Petro Vasylenko National Technical University of Agriculture, \\ Kharkiv, Ukraine \\ ${ }^{2}$ Ternopil Ivan Puluj National Technical University, Ternopil, Ukraine
}

\begin{abstract}
Summary.The assessment of a car fuel efficiency during operation using lubricants (motor and transmission oils) with fullerene compositions in a urban driving cycle is executed. Fullerene compositions were added to the engine and transmission oil at a mass concentration 10\%. The guiding document that defines the procedure for testing vehicles for fuel efficiency is GOST 20306-90.

Urban driving cycle tests were carried out on a truck ZIL-5301 "Bull" at an outside air temperature of $+20{ }^{\circ} \mathrm{C}$ (summer operation period) and at an outside air temperature of $-5^{\circ} \mathrm{C}$ (winter operation period).

It is established that operating a car in the urban driving cycle using of fullerene composition in both engine and transmission oils reduces the fuel consumption of the car by $14.54 \ldots 17.45 \%$ in the summer period. The value of $17.45 \%$ corresponds to the mileage of the car without cargo $(m=0)$, and the value of $14.54 \%-$ to the mileage with a cargo $(m=3000 \mathrm{~kg})$. The coefficient of variation of the measured value of fuel consumption was $0.039 \ldots 0.042$. This allows us to conclude that the measurement error is in the range of $3.9 \ldots 4.2 \%$.

When operating the car in the urban driving cycle in the winter operation period, the use of fullerene composition (mass concentration 10\%) Simultaneously in the engine oil and transmission oil reduces fuel consumption by $13.24 \ldots 15.15 \%$. The value of $15.15 \%$ corresponds to the mileage of the car without cargo $(m=0)$, and the value of $13.24 \%$ - mileage with cargo $(m=3000 \mathrm{~kg})$. The coefficient of variation of the measured value of fuel consumption was 0.039 ... 0.044. This allows us to conclude that the measurement error is in the range of 3.9 ... $4.4 \%$.
\end{abstract}

Key words: operation; vehicles; motor oils; transmission oils; fullerenes, fullerene compositions; volumetric fuel consumption; urban driving cycle.

https://doi.org/10.33108/visnyk_tntu2021.02.130

Received 19.04.2021

Relevance of the problem. When developing lubricants to improve tribological characteristics, complex compounds are used as additives, among which the industrial additive DF-11, which is zinc dialkyldithiophosphate, is the most widespread. Such additives contain atoms of sulfur, phosphorus and heavy metals, which increase the toxicity of exhaust gases, since when fuel is burned in engines, part of the engine oil also burns. It is known to use as additives to lubricants dispersions of functional nanosized particles of various origins (disulfide and trisulfide of molybdenum, wolfram, copper nanoparticles). Such compounds also contain metal atoms, which leads to increased carbon formation on engine parts and an increase in the toxicity of emissions [1].

It is now established [1] that adding non-toxic spherical clusters of fullerene $\mathrm{C}_{60}$ in the composition of technical oils, greases and lubricating coatings reduces the friction force, reduces wear and increases the anti-seize resistance of tribosystems. However, data on the effect of various fullerene derivatives on the lubricating properties of motor and transmission oils are insufficiently presented in the literature. According to the authors [1], this is due to the low solubility of nanosized fullerene particles in liquids. 
The use of fullerene additives to technical liquid lubricants raises a number of questions about their effectiveness, ie the impact on antiwear and antifriction properties. Interest in this phenomenon is of both fundamental and applied nature, which will make it possible to develop concepts for their application.

Analysis of recent research. In [2], comparative studies of different carbon materials ( $\mathrm{C}_{60}$ fullerene, soot containing and not containing $\mathrm{C}_{60}$, graphite, technical soot) as additives to industrial oil were performed. Fullerene soot and pure powdered fullerene $\mathrm{C}_{60}$ give a noticeable improvement of the antifriction and antiwear properties of the friction pairs steel-steel and copper-steel, especially in the area of high contact loads. It is shown that the presence of $\mathrm{C}_{60}$ (in pure form or in fullerene soot) leads to the formation on the friction surface of a fullerenopolymer film with a thickness of about $1000 \mathrm{~A}$, which is a protective film.

The work [3] is devoted to the study of the influence of additives containing fullerene $\mathrm{C}_{60}$ in industrial oil on the optimization of the process of limiting friction of steel and copper in steel-steel and copper-steel friction pairs. It is shown that the presence of fullerene in the oil leads to a significant reduction of the indicator, and for copper this parameter reaches quite low values, close to the conditional reference, previously selected for the ranking of solids by this indicator.

The authors of [4] present the results of studies of the influence of carbon nanoparticles (graphene, single and multi-walled nanotubes, as well as fullerene-containing nanomaterials) on the tribotechnical characteristics of industrial plastics and motor oils. It is shown that this effect depends not only on the carbon nanoparticles, but also on the base material, reducing or increasing the moment of friction forces. Adding nanoparticles in plastic lubricants increases the maximum load to the bulk and allows the use of plastic lubricants with nanoparticles selectively, depending on the requirements for friction units. Engine oil with nanotribos, containing fullerene, does not have a significant effect on the tribotechnical properties of the studied systems.

In paper [5], a new lubricating composition based on motor oil M-8-G2 (i) GOST 8581-78 (SAE 20) with impurities of pyrolytic graphite (fullerene soot) and nanosized fullerene particles was obtained. The formed surface films with highly dispersed nanosized fullerene particles on the modified surfaces of the engine's triboconjugations have a thickness (up to $0.1 \mathrm{~mm}$ ) sufficient to reduce the coefficient of friction, fuel consumption and improve vibration and noise characteristics of the diesel engine.

The authors of [6] presented a review of the literature on lubricants with adding of nanoparticles. The influence of nanoparticles on the tribotechnical characteristics of oils is analyzed. It is noted in the work that the use of nanoadditives to lubricants leads to an increase in the viscosity of the base medium, high bearing capacity of tribocompounds, reduction of the friction coefficient, increase of wear resistance. Work [7] concludes that recent efforts have focused on the development and use of carbon nanomaterials as additives to technical oils for car operation. The review presents the main achievements due to carbon nanolubricants, which will determine future developments.

The authors [8] proposed pre-dispersion of fullerenes in solvents, such as vegetable high oleic oils, and then the addition of such compositions to technical oils. According to the authors, this use of fullerenes gives a better positive effect than the addition of fullerenes in the form of nanopowders to the basic lubricants.

In [9], experimental studies of the effectiveness of fullerene compositions in motor oils and the degree of their impact on the effective power and specific fuel consumption of a 
diesel engine are presented. The weight of the fullerene composition is 100 gr. per kilogram of engine oil. The composition of the fullerene composition is $0.75 \mathrm{~g}$ of fullerenes and $99.25 \mathrm{~g}$ of rapeseed oil. The total weight of the fullerene composition is $100 \mathrm{gr}$., it was added to 1000 gr. Of base engine oil M-10G2k (mass concentration 10\%). The authors experimentally obtained the dependences of the effective power and specific fuel consumption using fullerene composition in motor oils. It is established that the use of motor oil with fullerene composition allows to obtain the following indicators when testing the diesel D-243 on the stand: the effective power of the diesel increased from $60 \mathrm{~kW}$ to $64.56 \mathrm{~kW}$, ie by $7.5 \%$; specific fuel consumption decreased from the values of $220 \mathrm{~g} / \mathrm{kWh}$ to $186 \mathrm{~g} / \mathrm{kWh}$, ie by $15.45 \%$. Based on the obtained experimental results, it is concluded that the use of fullerene composition in motor oils reduces the specific fuel consumption of the engine, which will save fuel during operation of vehicles without reducing their effective power.

From the analysis of the presented material it can be concluded that the use of fullerene compositions in technical lubricants is a promising area, for example, for the operation of vehicles. This will reduce friction losses in car units, which will lead to fuel savings while reducing the wear rate of materials of tribosystems and increase of a resource.

Formulation of research purpose. The aim of the work is an experimental study of the effectiveness of fullerene compositions in motor and transmission oils of vehicle units and the degree of their impact on fuel consumption during operation in the urban driving cycle.

Methodical approach in research. The guiding document that defines the procedure for testing vehicles for fuel efficiency is GOST 20306-90. This standard establishes the following indicators of fuel efficiency of vehicles:

- fuel consumption;

- fuel consumption in the main cycle on the road;

- fuel consumption in the urban cycle on the road.

The calculation of the above indicators is regulated by the relevant test program driving cycles.

According to GOST 20306-90 for trucks with a gross weight exceeding 3.5 tons, the urban driving cycle on the road is used as a test program. The numbers of operations when performing such a cycle, the sequence of operations and the mark of the path in meters are shown in Figure 1, the length of the measuring section is $4000 \mathrm{~m}$.

Test races were conducted on the ring road in one direction and were repeated at least three times to increase the accuracy of measurements, which meets the requirements of GOST 20306-90.

The distance of the ring road of 4000 meters was chosen without slopes and turns and pre-marked in proportion to the start number of the operation, which eliminated the errors of the driver when performing an urbandriving cycle.

Acceleration, deceleration during engine braking or service braking when the transmission is engaged with the use of service brakes were carried out in accordance with the requirements of the aforementioned standard.

At the moment of crossing the «zero» mark, recording devices were turned on, which measured the driving time with an accuracy of $0.1 \mathrm{~s}$ and the fuel consumption with an accuracy of $1.0 \mathrm{~cm}^{3}$. 


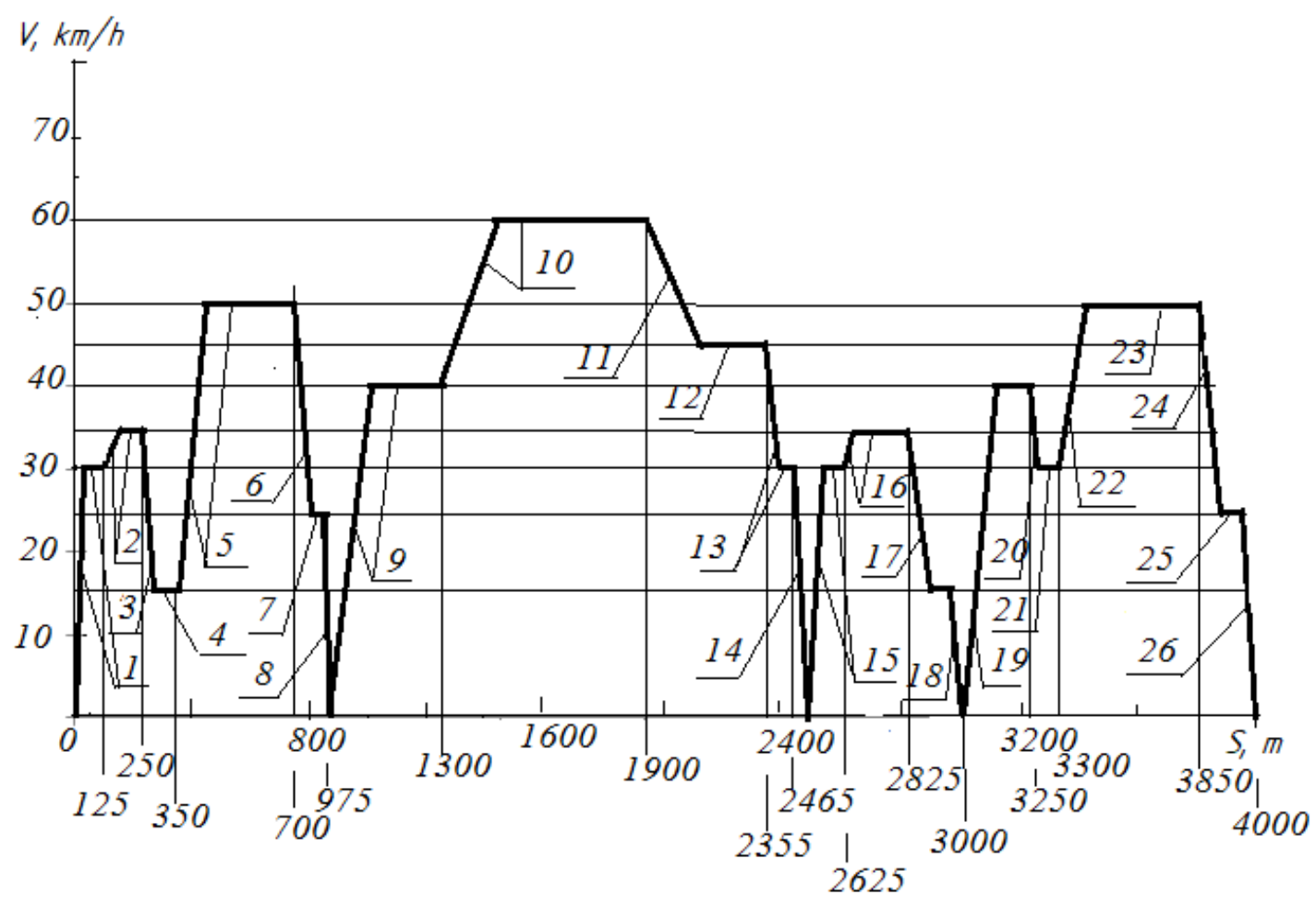

Figure 1. Scheme of the urban cycle on the road for trucks with a gross weight of more than 3.5 tons: 1 - acceleration to a speed of $30 \mathrm{~km} / \mathrm{h}$ and movement to the mark of $125 \mathrm{~m}$; 2 - acceleration to a speed of $35 \mathrm{~km} / \mathrm{h}$ and movement to the mark of $250 \mathrm{~m}$;

3 - braking to a speed of $15 \mathrm{~km} / \mathrm{h} ; 4$ - movement with a constant speed of $15 \mathrm{~km} / \mathrm{h}$ to the mark of $350 \mathrm{~m}$; 5 - acceleration to a speed of $50 \mathrm{~km} / \mathrm{h}$ and movement to the mark of $700 \mathrm{~m} ; 6$ - deceleration by the engine to a speed of $25 \mathrm{~km} / \mathrm{h} ; 7$ - movement at a speed of $25 \mathrm{~km} / \mathrm{h}$ to the mark of $975 \mathrm{~m} ; 8$ - braking to a complete stop, idling for $15 \mathrm{~s} ; 9$ - acceleration to a speed of $40 \mathrm{~km} / \mathrm{h}$ and movement to the mark of $1300 \mathrm{~m}$; 10 - acceleration to a speed of $60 \mathrm{~km} / \mathrm{h}$ and movement to the mark of $1900 \mathrm{~m} ; 11$ - deceleration by the engine to a speed of $45 \mathrm{~km} / \mathrm{h} ; 12$ - movement at a speed of $45 \mathrm{~km} / \mathrm{h}$ to the mark of $2355 \mathrm{~m}$;

13 - braking to a speed of $30 \mathrm{~km} / \mathrm{h}$ to the mark of $2465 \mathrm{~m}$; 14 - braking to a complete stop, idling for $15 \mathrm{~s}$; 15 - acceleration to a speed of $30 \mathrm{~km} / \mathrm{h}$ and movement to the mark of $2625 \mathrm{~m} ; 16$ - acceleration to a speed of

$35 \mathrm{~km} / \mathrm{h}$ and movement to the mark of $2825 \mathrm{~m} ; 17$ - deceleration by the engine to a speed of $15 \mathrm{~km} / \mathrm{h}$; 18 - braking to a complete stop, idling for $15 \mathrm{~s} ; 19$ - acceleration to a speed of $40 \mathrm{~km} / \mathrm{h}$ and movement to the mark of $3250 \mathrm{~m} ; 20$ - braking to a speed of $30 \mathrm{~km} / \mathrm{h} ; 21$ - movement at a speed of $30 \mathrm{~km} / \mathrm{h}$ to the mark of $3300 \mathrm{~m} ; 22$ - acceleration to a speed of $50 \mathrm{~km} / \mathrm{h}$;

23 - movement at a speed of $50 \mathrm{~km} / \mathrm{h}$ to the mark of $3850 \mathrm{~m} ; 24$ - braking to a speed of $25 \mathrm{~km} / \mathrm{h} ; 25$ - movement at a speed of $25 \mathrm{~km} / \mathrm{h}$ to the mark of $3975 \mathrm{~m}$; 26 - braking to a complete stop at the mark of $4000 \mathrm{~m}$

The following device is used to measure the fuel consumption in the conditions of the urban driving cycle, which consists of three units: a fuel consumption sensor, which is installed next to the fuel tank, an electronic switching unit, an indication and control unit. The fuel consumption sensor is installed in the fuel supply line before the filter-settling tank of the truck ZIL-5301 «Bull».

The fuel consumption sensor functions as a volumetric flowmeter and registers the volume of fuel that has passed through it in $\mathrm{cm}^{3}$.

The set of equipment used to perform driving cycles is shown in Figure 2. A personal computer with a specially written information processing program was used as a display and control unit. 


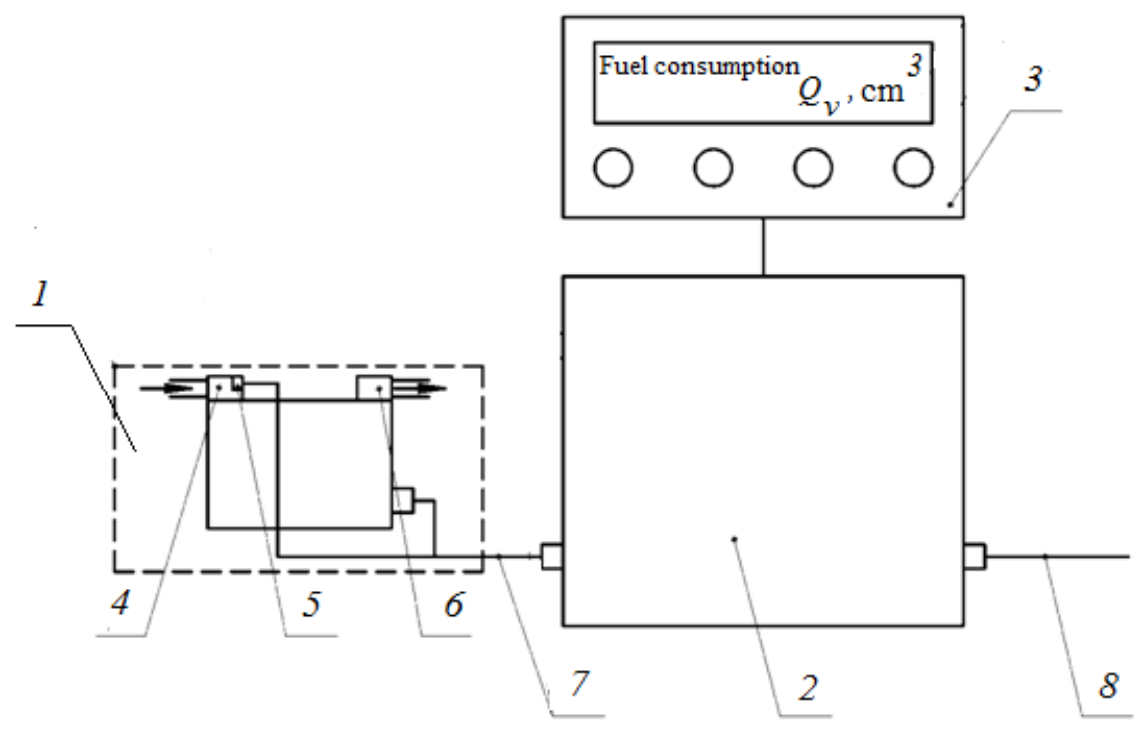

Figure 2. Scheme of the device for determining fuel consumption:

1 - fuel consumption sensor; 2 - electronic switching unit; 3 - display and control unit; 4 -inlet;

5 - temperature sensor; 6 - outlet; 7 - connecting cords; 8 - power cord

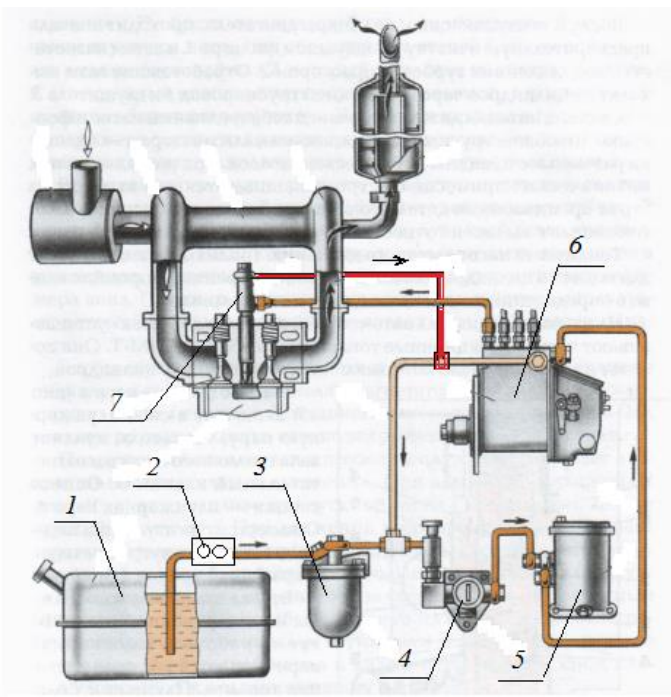

Figure 3. Scheme of the fuel system of the car ZIL 5301 «Bull»:

1 - fuel tank; 2 - fuel consumption sensor; 3 - filter settler; 4 - booster pump; 5 - fine filter; 6 - high pressure fuel pump; 7 - nozzle

To measure fuel consumption in the conditions of driving cycles used the fuel flowmeter IP-179, which was modified for research.

The modified device, Figure 2, consists of three units: a fuel consumption sensor 1, which is installed next to the fuel tank; electronic switching unit 2; display and control unit 3. The fuel consumption sensor is installed in the fuel supply line before the settling filter, as shown in Figure 3.

The fuel is supplied to the inlet 4 of the sensor 1 , which houses the temperature sensor 5, Figure 2. The fuel exits the sensor through the outlet 6 . The flowmeter sensor is connected by a cord 7 to the electronic switching unit 2 . The display and control unit 3 
displays fuel consumption. The device is powered by a voltage of $12 \mathrm{~V}$ through the cord 8 .

The fuel consumption sensor functions as a volumetric flowmeter and registers in $\mathrm{cm}^{3}$ the volume of fuel that has passed through it.

The device records the fuel temperature from the temperature sensor 5 with an interval of $0.5^{\circ} \mathrm{C}$. The temperature sensor DS18B20 with a measurement error of $\pm 0.5^{\circ} \mathrm{C}$ is used.

According to the measured time of driving cycles $t$, sec, and volumetric fuel consumption $Q, \mathrm{~cm}^{3}$, according to GOST 20306-90 the following indicators were calculated:

- the average speed of the vehicle during the test cycle with a length of $4000 \mathrm{~m}$ :

$$
V_{\text {avg }}=\frac{3.6 \cdot \mathrm{S}}{t_{\text {avg }}}, \mathrm{km} / \mathrm{h}
$$

- average fuel consumption:

$$
Q_{a v g}=\frac{25 \cdot Q}{S}, l / 100 \mathrm{~km} .
$$

where $S$ - the length of the measuring section, $4000 \mathrm{~m}$;

tavg - the average time spent on the passage of the measuring area, sec;

$\mathrm{Q}$ - volumetric fuel consumption measured by a flowmeter during the test cycle on a $4000 \mathrm{~m}$ section, $\mathrm{cm} 3$.

Research results. City driving cycle tests were carried out on the truck ZIL-5301 «Bull», which had a total mileage from the beginning of operation of 20 thousand $\mathrm{km}$. The car is equipped with a diesel turbocharger engine D 245.12 with a capacity of $73 \mathrm{~kW}$ and a specific fuel consumption $q=245 \mathrm{~g} / \mathrm{kW} \cdot \mathrm{h}$.

The tests were performed on a ring road with a straight section. All units of the car were warmed up by running on the ring road for at least $50 \mathrm{~km}$ at a speed of $2 / 3$ of the maximum before the start of the tests.

Control races began in the car, which used lubricants according to the operating instructions. API CC, SAE 40 engine oil was used in the engine lubrication system, and API GL-5, SAE 85W90 transmission oil was used in transmission units. Control races were repeated three times. The time of arrival was recorded with the help of a timer and the volumetric fuel consumption in $\mathrm{cm}^{3}$ with the help of a flowmeter.

At the end of three races, which used engine and transmission oils in accordance with the operating instructions, the oils were to be replaced. Fullerene composition of $10 \%$ mass concentration was added to the lubricants. After changing the lubricants the car ran at least 30 $\mathrm{km}$ on the ring road, after which there were three control races with registration of the time of arrival and the volume of fuel consumption.

The results of tests on the urban driving cycle at an outside air temperature of $+20^{\circ} \mathrm{C}$ (summer operation period) are presented in table 1.

Table 1 shows the average values of the test time $t_{\text {avg }}$ for three races, the volumetric fuel consumption $Q$ according to the measurement of the flowmeter, as well as the calculated values of the average speed, formula (1), average fuel consumption, formula (2).

The standard deviation of the fuel consumption was determined by the formula: 
Efficiency evaluation of using lubricants with fullerene compositions during operation of trucks in the urban driving cycle

$$
S_{Q}=\sqrt{\frac{1}{n} \sum_{i=1}^{n}\left(Q_{i}-Q_{\text {avg }}\right)^{2}},
$$

where $S_{Q}-$ standard deviation of fuel consumption, $1 / 100 \mathrm{~km}$;

$n$ - the number of repetitions that is equal to 3 ;

$Q_{i}$ - fuel consumption at each arrival, $1 / 100 \mathrm{~km}$;

$Q_{\text {avg }}$ - average fuel consumption in three races, $1 / 100 \mathrm{~km}$.

The coefficient of variation of the fuel consumption was determined by the expression:

$$
v_{Q}=\frac{s_{Q}}{Q_{\text {avg }}} .
$$

The percentage reduction in fuel consumption when using a fullerene composition in lubricants compared to normal operation:

$$
\varepsilon=\frac{Q_{n}-Q_{f c}}{Q_{n}},
$$

where $Q_{n}$ - fuel consumption of the car in normal operation, 1/100 km;

$Q_{f c}-$ fuel consumption by the car when using fullerene composition in lubricants, $1 / 100 \mathrm{~km}$.

Table 1

Test results of the car ZIL-5301 «Bull» on the urban driving cycle at an outside air temperature of $+20^{\circ} \mathrm{C}$

\begin{tabular}{|c|c|c|c|c|c|c|c|c|}
\hline $\begin{array}{c}\text { Weight of } \\
\text { cargo } m, \\
k g\end{array}$ & $\begin{array}{c}\text { Test } \\
\text { time } \\
t_{\text {avg }}, c\end{array}$ & $\begin{array}{c}\text { Volume fuel } \\
\text { consumption } \\
Q, \mathrm{~cm}^{3}\end{array}$ & $\begin{array}{c}\text { Average } \\
\text { speed } \\
V_{\text {avg }}, \mathrm{km} / \mathrm{h}\end{array}$ & $\begin{array}{c}\text { Fuel } \\
\text { consumption } \\
Q_{\text {avg }}, 1 / 100 \mathrm{~km}\end{array}$ & $\begin{array}{c}\text { The standard } \\
\text { deviation } S_{Q}, \\
1 / 100 \mathrm{~km}\end{array}$ & $\begin{array}{c}\text { Coefficient of } \\
\text { variation } v_{Q}\end{array}$ & $\begin{array}{c}\text { Reduction } \\
\text { percentage } \\
\varepsilon, \%\end{array}$ \\
\hline \multicolumn{7}{|c|}{ Regular mode of operation } \\
\hline 1500 & 477,2 & 3104 & 30,17 & 19,4 & 0,84 & 0,043 & - \\
\hline 3000 & 491,4 & 3264 & 29,30 & 20,7 & 0,91 & 0,043 & - \\
\hline & 468,3 & 2896 & 30,74 & 18,1 & 0,72 & 0,039 & - \\
\hline 0 & 452,8 & 2390 & 31,80 & 14,94 & 0,59 & 0,039 & 17,45 \\
\hline 1500 & 461,0 & 2580 & 31,23 & 16,13 & 0,69 & 0,042 & 16,85 \\
\hline 3000 & 474,9 & 2830 & 30,32 & 17,69 & 0,76 & 0,042 & 14,54 \\
\hline
\end{tabular}

From the analysis of the results shown in table 1, the following conclusions can be made. The use of fullerene composition (10\% mass concentration) simultaneously in motor and transmission oils reduces the fuel consumption of the car in the summer operation period on the urban driving cycle by $14.54 \ldots 17.45 \%$. The value of $17.45 \%$ corresponds to the mileage of the car without cargo $(m=0)$, and the value of $14.54 \%$ - mileage with cargo $(m=3000 \mathrm{~kg})$.

The coefficient of variation of the measured fuel consumption was $0.039 \ldots 0.042$. This allows us to conclude that the measurement error is in the range of $3.9 \ldots 4.2 \%$. 
The obtained result of a decrease in fuel consumption is equal to $14.54 \ldots 17.45 \%$, coincides with the results of bench tests of diesel D-243, which are given in [9].

Unambiguously, the increase in the mass of the transported cargo leads to a decrease in the effect of reducing fuel consumption and increasing the measurement error, while the coefficient of variation does not exceed 0.042 .

The results of tests of the car ZIL-5301 «Bull» in the urban driving cycle at an outside air temperature of $-5^{\circ} \mathrm{C}$ in the winter operation period are presented in table 2 .

Before the start of the tests, all the requirements of the GOST 20306-90, which were stated above, were fulfilled. The driver's cab heating system was connected to work.

Table 2

Test results of the car ZIL-5301 «Bull» on the urban driving cycle at an outside air temperature of $-5^{\circ} \mathrm{C}$

\begin{tabular}{|c|c|c|c|c|c|c|c|c|}
\hline $\begin{array}{c}\text { Weight of } \\
\text { cargo } m, \\
\mathrm{~kg}\end{array}$ & $\begin{array}{c}\text { Test time } \\
t_{\text {avg }}, c\end{array}$ & $\begin{array}{c}\text { Volume fuel } \\
\text { consumption } \\
Q, \mathrm{~cm}^{3}\end{array}$ & $\begin{array}{c}\text { Average } \\
\text { speed } \\
V_{\text {avg }}, \mathrm{km} / \mathrm{h}\end{array}$ & $\begin{array}{c}\text { Fuel } \\
\text { consumption } \\
Q_{\text {avg }}, 1 / 100 \mathrm{~km}\end{array}$ & $\begin{array}{c}\text { The standard } \\
\text { deviation } S_{Q}, \\
1 / 100 \mathrm{~km}\end{array}$ & $\begin{array}{c}\text { Coefficient of } \\
\text { variation } v_{Q}\end{array}$ & $\begin{array}{c}\text { Reduction } \\
\text { percentage } \\
\varepsilon, \%\end{array}$ \\
\hline \multicolumn{7}{|c|}{ Regular mode of operation } \\
\hline 1500 & 483,5 & 3232 & 29,78 & 20,2 & 0,9 & 0,044 & - \\
\hline 3000 & 500,0 & 3456 & 28,80 & 21,6 & 1,05 & 0,048 & - \\
\hline & & Fullerene compositions in lubricants, $10 \%$ mass concentration & 0,041 & 15,15 \\
\hline 0 & 463,0 & 2579 & 31,10 & 16,12 & 0,64 & 0,039 & 14,90 \\
\hline 1500 & 471,5 & 2750 & 30,54 & 17,19 & 0,74 & 0,043 & 13,24 \\
\hline
\end{tabular}

From the analysis of the results that are shown in table 2, the following conclusions can be made. The use of fullerene composition (10\% mass concentration) simultaneously in the engine and transmission oils in the winter operation period reduces fuel consumption by $13.24 \ldots 15.15 \%$. The value of $15.15 \%$ corresponds to the mileage of the car without cargo $(m=0)$, and the value of $13.24 \%$ - to the mileage with cargo $(m=3000 \mathrm{~kg})$.

The coefficient of variation of the measured fuel consumption was $0.039 \ldots 0.044$. This allows us to conclude that the measurement error is in the range of $3.9 \ldots 4.4 \%$.

Conclusions. The fuel efficiency of the truck ZIL-5301 «Bull» was evaluated during operation with the use of lubricants (engine and transmission oils) with fullerene compositions according to the urban driving cycle. Fullerene compositions were added to the engine and transmission oil at a $10 \%$ mass concentration.

It is established that during operation in the urban driving cycle in the summer period the use of fullerene composition in both engine and transmission oils reduces the fuel consumption of the car by $14.54 \ldots 17.45 \%$. The value of $17.45 \%$ corresponds to the mileage of the car without cargo $(m=0)$, and the value of $14.54 \%$ - to the mileage with cargo $(m=3000 \mathrm{~kg})$. The coefficient of variation of fuel consumption was $0.039 \ldots 0.042$. This allows us to conclude that the measurement error is in the range of $3.9 \ldots 4.2 \%$.

During truck operation in the urban driving cycle in the winter period the use of fullerene composition (10\% mass concentration) simultaneously in the engine and transmission oils reduces fuel consumption by $13.24 \ldots 15.15 \%$. The value of $15.15 \%$ corresponds to the mileage 
Efficiency evaluation of using lubricants with fullerene compositions during operation of trucks in the urban driving cycle

of the car without cargo $(m=0)$, and the value of $13.24 \%$ - mileage with cargo $(m=3000 \mathrm{~kg})$. The coefficient of variation of the measured fuel consumption was $0.039 \ldots 0.044$. This allows us to conclude that the measurement error is in the range of $3.9 \ldots 4.4 \%$.

\section{References}

1. Polunkin E. V., Kameneva T. M., Piljavskij V. S., Zhila R. S., Gajdaj O. A., Troshin P.A. Antiokislitel'nye i protivozadirnye svojstva galogenirovannyh fullerenov. Kataliz i neftehimija. 2012. No. 20. P. 70-74.

2. Gindzburg B. M., Bajdakova M. V., Kireenko O. F. [et]. Vlijanie fullerenov S60, fullerenovyh sazh i drugih uglerodnyh materialov na granichnoe trenie skol'zhenie metallov [Effect of C60 fullerenes, fullerene soots and other carbon materials on the boundary sliding friction of metals ]. Zhurnal tehnicheskoj fiziki. 2000. No. 12. P. 87-97. DOI: https://doi.org/10.1134/1.1333199

3. Tochil'nikov D. G., Ginzburg B. M. Vlijanie C60-soderzhashhih prisadok k smazochnomu maslu na optimizaciju processov iznashivanija pri granichnom trenii metallov [Influence of C60-Containing Lubricating Oil Additives on Optimization of Wear Processes at Boundary Friction of Metals] Zhurnal tehnicheskoj fiziki. 1999. Vol. 69. Issue 6. P. 102-105.

4. Gvozdev A. A., Smirnova A. I., Berezina E. V., Dunaev A. V., Tkachev A. G., Usol'ceva N.V. Issledovanie tribotehnicheskih harakteristik perspektivnyh smazochnyh materialov $\mathrm{s}$ uglerodnymi nanochasticami [Investigation of the tribological characteristics of promising lubricants with carbon nanoparticles]. Zhidk. krist. i ih praktich. ispol'z. Liq. Cryst. and their Appl. 2018. 18 (1). P. 66-72. DOI: https://doi.org/10.18083/LCAppl.2018.1.66

5. Jah'jaev N. Ja., Begov Zh. B., Batyrmurzaev Sh.D. Novaja smazochnaja kompozicija dlja modifikacii poverhnostej tribosoprjazhenij sudovogo malorazmernogo dizelja. Vestnik AGTU. Ser.: Morskaja tehnika i tehnologija. 2009. No. 1. P. 47-52.

6. Ankit Kotia, Krishna Chowdary, Isha Srivastava, Subrata Kumar Ghosh, Mohamed Kamal Ahmed Ali. Carbon nanomaterials as friction modifiers in automotive engines: Recent progress and perspectives. Journal of Molecular Liquids. Volume 310. 15 July 2020. P. 113-200. DOI: https://doi.org/10.1016/j.molliq.2020.113200

7. Shahmohamadi H., Rahmani R., Rahnejat H., Garner C. P., Balodimos N. Thermohydrodynamics of lubricant flow with carbon nanoparticles in tribological contacts. Tribology International. Volume 113. September 2017. P. 50-57. DOI: https://doi.org/10.1016/j.triboint.2016.12.048

8. Vojtov V. A., Kravcov A. G., and Tsymbal B. M. Evaluation of Tribotechnical Characteristics of Tribosystems in the Presence of Fullerenes in the Lubricant. FRICTION AND WEAR. 2020. Vol. 41. No. 6. P. 704-710. DOI: https://doi.org/10.32864/0202-4977-2020-41-6-704-710

9. Kravcov A. G. Ocinka efektivnosti zastosuvannja fulerenovih kompozicij $v$ motornih olivah pri ekspluataciï DVZ [Evaluation of the effectiveness of fullerene compositions in motor oils in the operation of internal combustion engines]. Tehnichnij servis agropromislovogo, lisovogo ta transportnogo kompleksiv. 2020. No. 21. P. 41-49. DOI 10.37700/ts.2020.21.41-49.

\section{Список використаної літератури}

1. Полункин Е. В., Каменева Т. М., Пилявский В. С., Жила Р. С., Гайдай О. А., Трошин П. А. Антиокислительные и противозадирные свойства галогенированных фуллеренов. Катализ и нефтехимия. 2012. № 20. С. 70-74.

2. Гиндзбург Б. М., Байдакова М. В., Киреенко О. Ф. и др. Влияние фуллеренов С60, фуллереновых саж и других углеродных материалов на граничное трение скольжение металлов. Журнал технической физики. 2000. № 12. С. 87-97. DOI: https://doi.org/10.1134/1.1333199

3. Точильников Д. Г., Гинзбург Б. М. Влияние С60-содержащих присадок к смазочному маслу на оптимизацию процессов изнашивания при граничном трении металлов. Журнал технической физики.1999. Том 69. Вып. 6. С. 102-105.

4. Гвоздев А. А., Смирнова А. И., Березина Е. В., Дунаев А. В., Ткачев А. Г., Усольцева Н. В. Исследование триботехнических характеристик перспективных смазочных материалов с углеродными наночастицами. Жидк. крист. и их практич. использ. Liq. Cryst. and their Appl. 2018. 18 (1). C. 66-72. DOI: https://doi.org/10.18083/LCAppl.2018.1.66

5. Яхьяев Н. Я., Бегов Ж. Б., Батырмурзаев Ш. Д. Новая смазочная композиция для модификации поверхностей трибосопряжений судового малоразмерного дизеля. Вестник АГТУ. Сер.: Морская техника и технология. 2009. № 1. С. 47-52.

6. Ankit Kotia, Krishna Chowdary, Isha Srivastava, Subrata Kumar Ghosh, Mohamed Kamal Ahmed Ali. Carbon nanomaterials as friction modifiers in automotive engines: Recent progress and perspectives. Journal of Molecular Liquids. Volume 310. 15 July 2020. P. 113-200. DOI: https://doi.org/10.1016/j.molliq.2020.113200 
7. Shahmohamadi H., Rahmani R., Rahnejat H., Garner C.P., Balodimos N. Thermohydrodynamics of lubricant flow with carbon nanoparticles in tribological contacts. Tribology International. Volume 113. September 2017. P. 50-57. DOI: https://doi.org/10.1016/j.triboint.2016.12.048

8. Vojtov V. A., Kravcov A. G., and Tsymbal B. M. Evaluation of Tribotechnical Characteristics of Tribosystems in the Presence of Fullerenes in the Lubricant. FRICTION AND WEAR. 2020. Vol. 41, No. 6. P. 704-710. DOI: https://doi.org/10.32864/0202-4977-2020-41-6-704-710

9. Кравцов А. Г. Оцінка ефективності застосування фулеренових композицій в моторних оливах при експлуатації ДВ3. Технічний сервіс агропромислового, лісового та транспортного комплексів. 2020. № 21. C. 41-49. DOI 10.37700/ts.2020.21.41-49.

\title{
УДК 621.891
}

\section{ОЦІНЮВАННЯ ЕФЕКТИВНОСТІ ЗАСТОСУВАННЯ ЗМАЩУВАЛЬНИХ МАТЕРІАЛІВ 3 ФУЛЕРЕНОВИМИ КОМПОЗИЦІЯМИ ПРИ ЕКСПЛУАТАЦІЇ ВАНТАЖНИХ АВТОМОБІЛІВ У МІСЬКОМУ ЦИКЛІ}

\author{
Андрій Кравцов ${ }^{1}$; Микола Карнаух ${ }^{1}$; Любомир Слободян ${ }^{2}$ \\ ${ }^{1}$ Харківський національний технічний університет сільського \\ господарства імені П. Василенка, Харків, Украӥна \\ ${ }^{2}$ Тернопільський національний технічний університет імені Івана Пулюя, \\ Тернопіль, Україна
}

\begin{abstract}
Резюме. Виконано оцінювання паливної економічності автомобіля при експлуатації 3 використанням змашувальних матеріалів (моторні та трансмісійні оливи) з фулереновими композиціями за міським їздовим ичиком. Фулеренові композииї додавалися до моторної й трансмісійної оливи в концентрації 10\% мас. Керівним документом, який визначає порядок випробувань автотранспортних засобів на паливну економічність, є ГОСТ 20306-90.

Випробування за міським їдовим ииклом проводилися на вантажному автомобілі 3ІЛ-5301 «Бичок» при температурі навколишнього повітря $+20^{\circ} \mathrm{C}$ (літній період експлуатаціі) та при температурі навколишнього повітря $-5{ }^{\circ} \mathrm{C}$ (зимовий період експлуатації).

Встановлено, щзо при експлуатаиії автомобіля за міським їзовим ичиклом у літній період експлуатації застосування фулеренової композиції одночасно в моторній і трансмісійній оливах зменшує витрату пального автомобіля на 14,54 ... 17,45\%. При изьому величина 17,45\% відповідає пробігу автомобіля без вантажу $(m=0)$, а величина 14,54\% - пробігу з вантажем $(m=3000$ кг). Коефіцієнт варіації вимірюваної величини витрати пального склав 0,039 ... 0,042. Це дозволяє зробити висновок, щзо похибка вимірювань знаходиться в межах 3,9 ... 4,2\%.

При експлуатації автомобіля за міським їздовим цүиклом у зимовий період експлуатації застосування фулеренової композиції (концентрація 10\% мас.) одночасно в моторній $і$ трансмісійній оливах зменшує витрату пального на 13,24 ... 15,15\%. При изьму величина 15,15\% відповідає пробігу автомобіля без вантажу $(m=0)$, а величина 13,24\% - пробігу з вантажем (m=3000 кг). Коефіиієнт варіації вимірюваної величини витрати пального склав 0,039 ... 0,044. Це дозволяє зробити висновок, щуо похибка вимірювань знаходиться в межах 3,9 ... 4,4\%.
\end{abstract}

Ключові слова: експлуатація, засіб транспорту, моторні оливи, трансмісійні оливи, фулерени, фулеренові композиції, об'ємна витрата пального; міський їзовий цүикл. 